\title{
Vitamin D Binding Protein (VDBP) and Its Gene Polymorphisms-The Risk of Malignant Tumors and Other Diseases
}

\author{
Dominika Rozmus ${ }^{1}{ }^{\oplus}$, Alicja Ciesielska ${ }^{1}$, Janusz Płomiński ${ }^{2,3}$, Roman Grzybowski ${ }^{2,3}$, \\ Ewa Fiedorowicz ${ }^{1}$, Natalia Kordulewska ${ }^{1}{ }^{\circledR}$, Huub Savelkoul ${ }^{4}{ }^{\circledR}$, Elżbieta Kostyra ${ }^{1}$ \\ and Anna Cieślińska ${ }^{1, *(1)}$ \\ 1 Faculty of Biology and Biotechnology, University of Warmia and Mazury, 10-719 Olsztyn, Poland; \\ dominika.rozmus@uwm.edu.pl (D.R.); alicja.staruch@wp.pl (A.C.); ewa.kuzbida@uwm.edu.pl (E.F.); \\ natalia.smulska@uwm.edu.pl (N.K.); ezlbieta.kostyra@uwm.edu.pl (E.K.) \\ 2 Clinical Department of Trauma-Orthopedic Surgery and Spine Surgery of the Provincial Specialist Hospital \\ in Olsztyn, 10-561 Olsztyn, Poland; plominsky@poczta.onet.pl (J.P.); romek.grzybowski@wp.pl (R.G.) \\ 3 Department and Clinic of Orthopaedics and Traumatology, Collegium Medicum, University of Warmia and \\ Mazury, 10-719 Olsztyn, Poland \\ 4 Cell Biology and Immunology Group, Department of Animal Sciences, Wageningen University and \\ Research, 6700 AG Wageningen, The Netherlands; huub.savelkoul@wur.nl \\ * Correspondence: anna.cieslinska@uwm.edu.pl; Tel.: +48-89-523-36-67
}

Received: 27 August 2020; Accepted: 20 October 2020; Published: 22 October 2020

check for updates

\begin{abstract}
Vitamin D is an important component of the endocrine system that controls calcium homeostasis and bone mineralization. Because of the very short half-life of free serum vitamin D it is stabilized and transported to target tissues by being bound to the vitamin D binding protein (VDBP). The most common polymorphisms: rs4588 and rs7041 in the vitamin D binding protein gene may correlate with differences in vitamin D status in the serum. This review presents data that relate to the presence of genetic variants in the VDBP gene in correlation with certain diseases, mostly concerning cancers (breast, prostate, pancreatic, lung, colorectal, basal cell carcinoma cancer and cutaneous melanoma) or other related diseases (thyroid autoimmunity disorders, obesity, diabetes mellitus, bone metabolism, rheumatoid arthritis, ankylosing spondylitis, asthma, chronic obstructive pulmonary disease, tuberculosis and coronary artery diseases).
\end{abstract}

Keywords: vitamin D binding protein; vitamin D; VDBP; SNP; single nucleotide polymorphism; cancer; [25(OH)D]

\section{Introduction}

Vitamin D plays a crucial role in the endocrine system which controls calcium homeostasis in the whole body [1] and along with parathyroid hormone-bone mineralization [2]. A proper 25-hydroxyvitamin vitamin $\mathrm{D}[25(\mathrm{OH}) \mathrm{D}]$ status helps to maintain a healthy body weight and prevents obesity [3]. Vitamin D takes part in innate and adaptive immunity and is involved in the detoxification of bile acids [4], it plays important role in intestinal homeostasis by limiting microbiota entrance into interstitium and regulates the immune system by favoring formation of Treg cells and suppressing Th1/Th17 cells [5]. Vitamin D receptor (VDR), enzymes and metabolites have different expression levels in various types of immune cells such as lymphocytes, monocytes, macrophages and dendritic cells $[6,7]$.

Vitamin D is classified as a steroid hormone with wide regulatory effects. It affects regulation of the expression of many different genes that are involved in the differentiation, activation and proliferation of 
many cell types. The active form of vitamin D may inhibit the expression of interleukin 2 and interferon $\gamma$ and affect the differentiation and maintenance of the balance of regulatory cells [8]. The action of vitamin $\mathrm{D}$ in cells requires the presence of nuclear and cytosolic vitamin $\mathrm{D}$ receptors (VDR). VDR binds the vitamin D active metabolite: 1 $\alpha, 25$-dihydroxyvitamin D3. VDR is expressed in nerve cells, glial cells and cells of the immune system, such as monocytes, macrophages and activated T and B lymphocytes, as well as in cancer cells (colon cancer) and liver stellate cells. The presence of these receptors allows for the regulation of gene expression involved in organ development, cell cycle control, calcium and phosphate homeostasis in bone metabolism and xenobiotic detoxification. Research literature suggests that up to 500-1000 genes can be modulated by VDR ligands [9].

Human can synthesize vitamin D under UVB radiation exposure or obtain it through oral intake from diet and supplements [10]. There are two major forms of the vitamin D, D3 (cholecalciferol), which is an animal form and D2 (ergocarciferol), which is present in plants but mostly in fungi and yeasts [11-13]. The diet or ingestion of supplements can be an important source for vitamin D in humans. Vitamin D3 can be synthesized endogenously and it is produced by the skin upon UVB exposure [13]. The photoproduction of vitamin D in the skin begins with the synthesis of 7-dehydrocholesterol (7-DHC) (Figure 1). 7-dehydroholesterol (7-DHC) is built into the cell membranes of the epidermis and dermis. When exposed to solar UVB, 7-DHC is converted into pre-vitamin D3, which is isomerized to cholecalciferol in the cell membrane by a subsequent thermal isomerizatoin [10]. The cholecalciferol produced is removed to the extracellular space and reaches the capillary in the dermis by diffusion. Cholecalciferol is transported to the liver by the vitamin $\mathrm{D}$ binding protein (VDBP) and then it is converted to 25-hydroxyvitamin D [25(OH)D3, calcidiol]. 25(OH)D3 is the major circulating metabolite of vitamin $\mathrm{D}$, which is hydroxylated in the kidney by 1-alpha-hydroxylase to its active form: 1,25-dihydroxyvitamin $\mathrm{D}\left[1,25(\mathrm{OH})_{2} \mathrm{D} 3\right.$, calcitriol] [14]. Conversion from calcidiol to calcitriol also occurs in nonrenal tissues and cells (NRTCs): skin, parathyroid glands, bone cells, cardiovascular and immune cells [15].

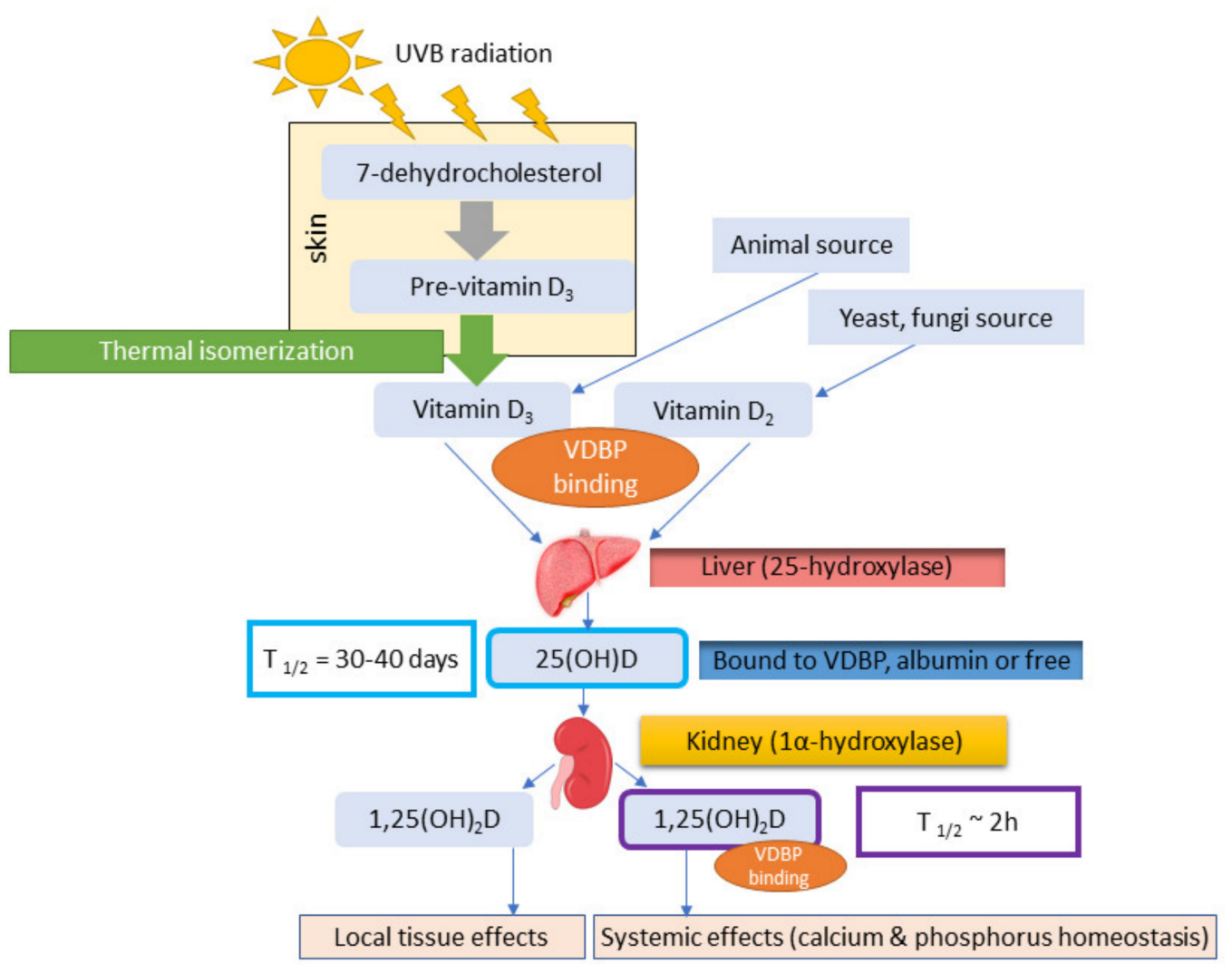

Figure 1. Vitamin D synthesis pathway (based on Bikle 2014 [14]). 
Low vitamin D status have been linked to bone mineralization defects, as well as common chronic, autoimmune and infectious diseases including cancer, cardiovascular disease, diabetes, multiple sclerosis, rheumatoid arthritis and tuberculosis [16-29]. Other studies do not support the theory of protective effects of vitamin D in cancer or cardiovascular disease: taking up to $2000 \mathrm{IU}$ of vitamin D per day by men and women had no reduction in invasive cancer or major cardiovascular cases compared to placebo group. Supplementation of vitamin D with $2000 \mathrm{IU}$ dose was not associated with lower risk of having invasive cancer or composite of major cardiovascular event such as myocardial infarction, stroke or death due to cardiovascular causes. However, hazard ratio of incidence to any invasive cancer was lower among participants with BMI < 25 [30]. Meta-analysis of randomized controlled trial (RCTs) proved that vitamin D supplementation reduces total cancer mortality but do not reduce total cancer incidence [31]. Study of Barbarawi's et al. including RCTs $(83,291$ patients with 41,622 placebo ones) showed that vitamin D supplementation was not associated with reduced major cardiovascular events [32].

Our review was conducted by searching phrases: "rs7041/rs4855 + disease"; vitamin d binding protein polymorphism; vitamin d binding protein polymorphism + disease; Gc globulin polymorphism + disease, rs7041/rs4855 + cancers; rs7041/rs4855 + chronic diseases; VDBP + disease; DBP + disease; 25-hydroxyvitamin D cancers; 25-hydroxyvitamin D + diseases; VDBP polymorphism disease; VDBP SNP disease. Google scholar and PubMed databases were used.

\section{Vitamin D and Gene Regulation}

When 1,25(OH)2D3 is attached to the nuclear and cytosolic vitamin D receptors (VDR), it is able to regulate many genes, including the genes encoding osteocalcin, osteopontin and Cyp24a1, as well as Vdr, Cbs, Tnfsf11, c-FOS, Spp1, Runx2, Cdon, Mmp13, Col2a, Trpv6, S100g and others [14,33]. The active transcription unit in 1,25(OH)2D3-mediated gene regulation is the VDR/RXR heterodimer. There are approximately 2000-8000 binding sites in human genome for VDR and the distal-binding site is distributed across the genome in cis-regulatory modules (enhancers or CRM). The number and location of those sites depend on the cell type but they can be found near promoters, mainly within introns or in distal intergenic regions and also in clusters of elements. VDR/RXR-binding site sequence (vitamin D responsive element, VDRE) can be inducted by classic hexameric half-sites (AGGTCA) separated by three base pairs. CRMs contain binding sites for many types of transcription factors [34-36]. Comparison of the VDR/RXR cistrome in early precursors and late mineralizing osteoblasts showed a reduction in the number of VDR binding sites in more mature cells and a reduction in their sites, especially near genes that were no longer responsive to 1,25(OH)2D3 [36].

\subsection{Vitamin D3 and D2}

Dietary sources of vitamin D include cholecalciferol (vitamin D3) and ergocalciferol (vitamin D2) [4]. Vitamin D3 is naturally produced in the skin of animals, including humans and vitamin D2 is produced in fungi, yeast and plants after exposure to sunlight and UVB radiation [19,37] (Figure 2). 

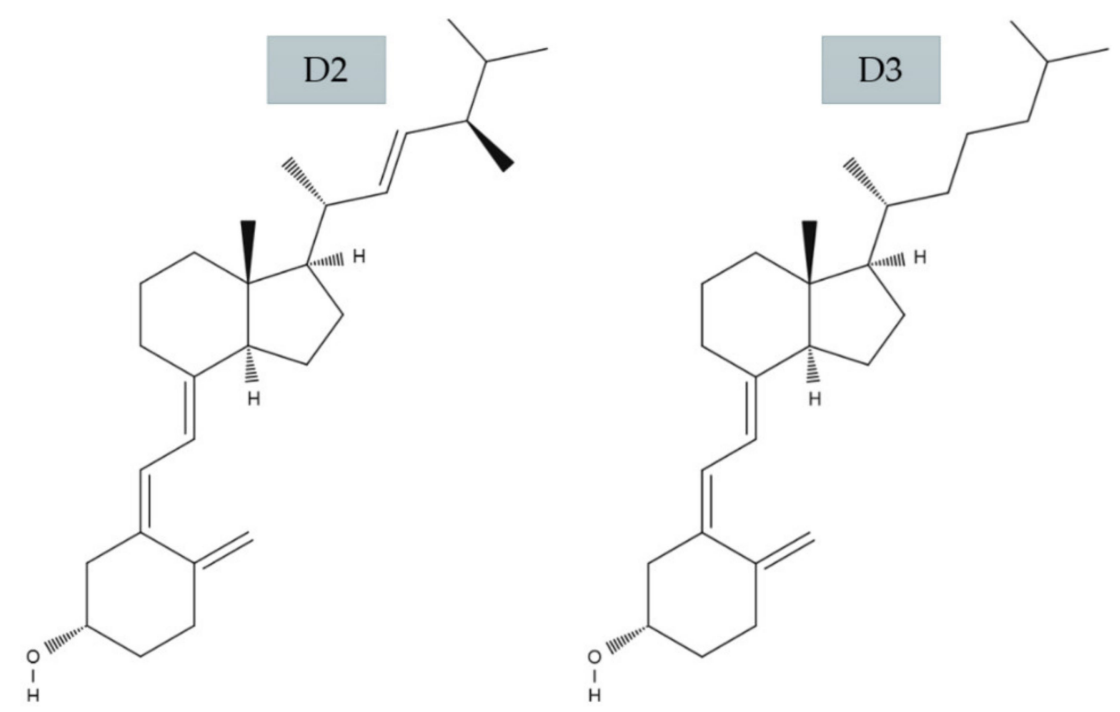

Figure 2. Molecular structure of vitamin D2 and D3 (based on Holick 2018 [38]).

Vitamin D2 (C28H44O) differs from D3 (C27H44O) by a side chain attached to the secosteroid backbone that contains a group set at carbon 24 and a double bond between carbon atoms 22 and 23. This difference means that the curb mass of D2 $(396.65 \mathrm{~g} / \mathrm{moL})$ is $3.1 \%$ richer than vitamin D3 $(384.64 \mathrm{~g} / \mathrm{moL})$ [39]. There are many studies proving that vitamin D3 has a much stronger effect than vitamin $\mathrm{D} 2$ by measuring 25(OH)D concentrations in both serum and adipose tissue [20,40-43].

\subsection{Role of $V D B P$}

Vitamin $\mathrm{D}$ binding protein is a serum $\alpha 2$-globulin of 52-59 $\mathrm{kDa}$ molecular weight. Originally it was called "group-specific component"-Gc [44]. The encoding VDBP gene (35kb DNA with 13 exons, 12 introns) is located on the long arm of the chromosome 4 (4q12-q13). VDBP belongs to the albumin superfamily of binding proteins (albumin, alfa-fetoprotein, alfa-albumin/afamin). They are expressed in the liver [45-47].

VDBP has many biological functions: binding and transporting of all vitamin D metabolites: (25OHD lactone $>25 \mathrm{OHD}=24,25(\mathrm{OH}) 2 \mathrm{D}=25,26(\mathrm{OH}) 2 \mathrm{D}>1,25(\mathrm{OH}) 2 \mathrm{D}>$ vitamin $\mathrm{D}$ and vitamin $\mathrm{D} 3$ metabolites > vitamin D2 metabolites), binding of actin monomers and playing a crucial role in depolymerization of extracellular actin filaments [48], binding of fatty acids [34] binding to membranes proteoglycans of leucocytes and activation of complement C5 system [35].

\subsection{VDBP Gene Family Polymorphism}

The VDBP amino acid sequence consists of 458 amino acids arranged over three domains. The 16 $\mathrm{N}$-terminal amino acids act as a signal peptide. VDBP can be glycosylated to a varying degree depending on the genotype [49]. The two SNPs—rs7041 and rs4588-in exon 11, located in domain III, correspond to the three major VDBP types (VDBP1F, VDBP1S and VDBP2). Apart from them, over 120 other types are distinguished [50].

These phenotypic alleles differ by a single-nucleotide polymorphisms (SNP) in exon 11: rs7041 and rs4588 and also by a glycosylation pattern [51]. An amino acid substitution difference of GC1F and GC1S occurs in position 416, where aspartic acid is substituted by glutaminic acid. The difference between GC1F and GC2 is a single amino acid substitution from threonine to a lysine (ACG to AAG) [52,53]. It is known that GC1 and GC2 are marked by an O-glycolisation [52], while GC1F and GC1S are modified with a N-acetyl-D-glucosamine core [54].

Alleles frequency has been examined and less predominance is shown for GC2 allele in comparison to GC1 allele and also GC1F allele has a lower frequency for white skin population, while the highest frequency was found for the GC1S allele. GC1F frequency for dark skin populations can explain its 
efficient transport of vitamin D metabolites. Skin pigmentation and intensity of sunlight exposure might thereby correlate with VDBP frequencies of human populations. It is known that more pigmented or keratinized skin types have a lower UV light penetration level and the higher risk of susceptibility to rickets [55].

Other studies have corelated SNPs of the VDBP gene to status of circulating 25(OH)D. An inverse correlation was found in Germany, where the number of rarer alleles of VDBP gene SNPs [rs4588 $(\mathrm{C}>\mathrm{A}), \mathrm{rs} 2282679(\mathrm{~A}>\mathrm{C})$ or rs1155563 (T>C)] was associated with higher hydroxyvitamin D status, mostly during summer. That can be explained by the hypothesis that genetic differences have an impact on interindividual variations of vitamin D status and responses to sun exposure-UVB radiation-which is a season-dependent environmental factor [56,57]. Another study shows that status of 25(OH)D were strongly related to VDBP polymorphisms in both SNPs: rs7041 and rs4588, especially when there is a high concentration of vitamin D in need of transportation [57].

Table 1 presents the characteristics of VDBP main polymorphism types.

Table 1. Characteristics of vitamin D binding protein (VDBP). VDBP polymorphisms (based on Bouillon $2020[53])$.

\begin{tabular}{cccc}
\hline SNP Locus & GC Name & Codon Variant & Amino Acid Variant \\
\hline Rs4588 & GC1 & ACG (Thr->Lys) & Thr-436 \\
\hline Rs4588 & GC2 & AAG (Thr->Lys) & Lys-436 \\
\hline Rs7041 & GC1F & GAT (Asp->Glu) & Asp-432 (416/mature VDBP) \\
\hline Rs7041 & GC1S & GAG (Asp->Glu) & Glu-432 (420/mature VDBP) \\
\hline
\end{tabular}

\section{Association of VDBP with Human Diseases}

\subsection{Cancers}

\subsubsection{Breast Cancer}

Abbas et al. in 2008 examined vitamin D pathway gene polymorphisms and association of VDBP with postmenopausal breast cancer risk. $25(\mathrm{OH}) \mathrm{D}$ as a biomarker for vitamin D concentration in humans was also a part of the study. $25(\mathrm{OH}) \mathrm{D}$ and VDBP polymorphisms have an impact on the decreasing risk of postmenopausal breast cancer. Also, there was no association between $25(\mathrm{OH}) \mathrm{D}$ status and VDBP type. Decreased risk of postmenopausal breast cancer was noted for GC2 allele in VDBP. The mechanism underlying this process is probably an anticancerogenic effect associated with Gc potential to convert Gc to GcMAF-a macrophage activator [51,54]. VDBP is required for proper macrophage activation. When a neoplastic tissue is present, Gc-globulin is hydrolyzed and activated with the sialidase of $\mathrm{T}$ lymphocytes and $\beta$-galactosidase to yield a highly potent MAF. Conversion of Gc-globulin to Gc-MAF makes macrophages activated to phagocytosis of cancer cells [58,59]. Recent studies show that immunotherapy with GcMAF has promising results in breast cancer therapy because of the potential of macrophages to infiltrate tumors and their crucial role in antitumor immunity. Macrophages activated by GcMAF can recognize, internalize and eliminate not only cancerous cells but also bacteria [60]. Another study shows association between VDBP rs7041 and breast cancer [61]. It is important to mention that a recent study showed that higher $25(\mathrm{OH}) \mathrm{D}$ concentrations $(\geq 60 \mathrm{ng} / \mathrm{mL})$ had the most protective effect in decreasing the breast cancer risk for about $80 \%$ [62]. Among women, plasma concentrations of $\geq 40 \mathrm{ng} / \mathrm{mL} 25(\mathrm{OH}) \mathrm{D}$ were associated with a substantial reduction on the risk of all invasive cancers combined [63].

\subsubsection{Prostate Cancer}

Weinsten et al., (2012) reported a significant association between men with higher 25(OH)D status and the risk of prostate cancer. Status of $25(\mathrm{OH}) \mathrm{D}$ free fraction were also a part of the study, 
as well as VDBP serum concentration. Higher VDBP was related to decreased risk among men with lower 25(OH)D concentration. Speculation about the underlying mechanism was directed at higher levels of VDBP that may bind more vitamin D by prostatic epithelium. Prostate tissue was shown to express megalin that has functions in absorption of many molecules, also hormones as SHGB. SHGB-bound testosterone was associated with prostate tumor progression. 25(OH)D and testosterone status are associated [64]. However, another study does not show any significant correlation with protective association between higher vitamin D status and lower risk of prostate cancer. Moreover, correlation between rs2282679 and risk of prostate cancer was rejected [65]. More recent meta-analyses are contradictory: the highest concentration of $25(\mathrm{OH}) \mathrm{D}$ is associated with an elevated risk of prostate cancer [66], while the vitamin D intake can decrease the risk of PC [67]. Moreover, vitamin D has influence on phosphorus homeostasis and phosphorus is association with risk of lethal and high-grade prostate cancer. Twenty four-year follow-up study suggested that calcium intake $>2000 \mathrm{mg}$ per day were associated with higher risk of total prostate cancer and phosphorus intake was associated with higher risk of total, lethal and high-grade cancers [68]. Calcium intake was associated with aggressive prostate cancer and vitamin D intake had inverse effect. However, those associations are race-, ethnicityand BMI-dependent [69].

\subsubsection{Pancreatic Cancer}

The interaction between VDBP and 25(OH)D was examined by Weinsten et al., (2012). The study shows association between higher concentration of circulating 25(OH)D and raised pancreatic cancer risk. Men with higher concentrations of 25(OH)D and VDBP in serum showed elevated risk of pancreatic cancer [64]. Another study found no relation of VDBP to pancreatic cancer [70]. Meta-analysis of Gc polymorphisms rs2282679, rs7041 and rs4588 found no significant correlation with pancreas cancer [71].

\subsubsection{Lung and Colorectal Cancer}

A study showed that a low VDBP level in serum might be a predictor of subsequent death from lung cancer because the expression of VDBP gene is rather low or absent in lung cancer tissue [72]. The underlying mechanism might be the Gc potential to be converted into GcMAF (described in Breast Cancer subsection) and its subsequent antitumor effect. A second mechanism might be the potential of macrophages to convert 25OHD3 to 1,25(OH)2D3. $25 \mathrm{OHD} 3$ can be converted into $1,25(\mathrm{OH}) 2 \mathrm{D} 3$ by macrophages or other cells that express $1 \alpha$-hydroxylase [72,73]. A study that proved correlation of VDBP polymorphisms with lung cancer was conducted among Thai patients. The TT-CA combination had protective association with lung cancer. The same study proved also that rs7041 (TG/GC) polymorphism was associated with colorectal cancer among 60 years and older patients. Rs4588 (CA/AA) polymorphism was associated with colorectal cancer among 60 years old and younger man [74]. Another study showed a significant correlation between rs7041 in the GC gene and a reduction in Non-Small Cell Lung Cancer risk [75]. Carrying both polymorphisms: rs7041 polymorphism in Gc and CYP2R1/rs10741657 (enzyme for 25-hydroxylase that converts vitamin D to 1,25(OH)2D3) decreases the risk of colorectal cancer about 9-12\% [76].

\subsubsection{Basal Cell Carcinoma}

Basal cell carcinoma is the most common cancer in Caucasians but there was no significant correlation with susceptibility to one or multiple BCCs in general. At the same time, among 6 patients GC1F was noted to have a decreased risk of developing the first BCC, while among other patients with heterozygous GC1F genotype, there was a higher chance for a first BCC development. Although, Rs7041 and rs4588 may thus be associated with BCC development among younger patients but those speculations required more studies at the time [77]. 


\subsubsection{Cutaneous Melanoma}

Cutaneous Melanoma is caused by a transformation of melanocyte and pigment producing cells. The response on exposure to UV induces the production of melanin by these cells. The association between VDBP rs12512631 and the risk of cutaneous melanoma was shown in a study that was conducted among a Spanish population, as the exposure to the sun is higher than in the other European countries, especially northern ones. This association was explained only by the fact that VDBP variants can modulate this protein expression besides its activity which may affect vitamin synthesis and its distribution [78]. A meta-analysis showed that the VDBP rs12512631 C allele was significantly associated with survival of CM patients. The explanation that was provided suggested that rs12512631 may affect the corresponding gene's function or the vitamin D plasma status and subsequently modulated the risk of death [79]. Schäfer et al., in 2012 showed the analysis of VDBP rs1155563 and rs7041 for their association with melanoma risk and prognosis. However, none of these two polymorphisms was associated with melanoma risk [80].

\subsection{Other Important Diseases}

\subsubsection{Diabetes Mellitus}

The study of Hirai et al. in 2000 showed that a polymorphism of VDBP was associated with insulin resistance in Japanese with normal glucose tolerance. That may lead to type 2 diabetes development. This insulin resistance was different among the VDBP genotype since GC1S-2 and 1S-1S genotypes had higher fasting plasma concentration compared to 1F-1F [81,82]. Also another study on Pakistani population showed the association of VDBP to type-2 diabetic patients. In addition, vitamin $\mathrm{D}$ deficiency was correlated with an increased incidence of diabetes [83]. A recent study shows that rs7041 (Glu/Glu-416) and rs4588 (Lys/Lys-420) variants of VDBP were higher in type 2 diabetic comparing to control group. A higher risk of developing type 2 diabetes was associated among patients with Glu/Glu and Lys/Lys genotypes at codon 416 and 420, respectively [84]. Another recent study on the group of 2423 patients shows no connection between vitamin D insufficiency and higher risk of type 2 diabetes [85].

\subsubsection{Thyroid Autoimmunity Disorders}

As vitamin D serum status among patients with Graves' disease were lower compared to patients with nonautoimmune hyperthyroidism, an influence of VDBP polymorphism on the disease risk was suggested. Indeed, intron 8 (TAAA)n-Alu repeat polymorphism correlates with Graves' disease $(n=561)$ but there is no association with Hashimoto's thyroiditis [86]. Another study showed that VDBP polymorphisms may contribute to development of autoimmune diseases and they are associated with susceptibility to Grave disease in Polish population. Variations of VDBP might have influence on many immune functions [87].

\subsubsection{Obesity}

VDBP has its function in the vitamin D and glucose metabolism and it is also associated with insulin resistance. A study showed a correlation between different SNPs and obesity among women, especially with respect to the percentage of fat mass (PFM) [88]. Insufficiency of vitamin D among obese people might thus be the result of decreased bioavailability of vitamin D3 and this bioavailability might be decreased because of vitamin D3 deposition in body fat mass compartments [89].

\subsubsection{Bone Metabolism}

Powe et al. in 2011 showed that total 25(OH)D concentration status was positively correlated with VDBP levels but levels of VDBP-25(OH)D had no association with BMD (bone mineral density) [90]. This study was criticized and the apparent paradox was explained. Powe's estimations were found 
incorrect because of the indirect method used for estimating of free 25(OH)D [91]. A recent study proved that low serum VDBP levels correlate with low BMD and that is why VDBP could have a potential as a non-invasive biomarker for early osteoporosis detection. The study focused on a group of postmenopausal women aged $\geq 45$ years old but also had limitations as low BMD is not a disease marker but it reflects the bone status. Defining a sensitive and predictive biomarker for osteoporosis detection would thus be beneficial for such patients [92]. VDBP is the key for regulating calcium homeostasis. A study showed 13 SNPs among postmenopausal Japanese women and analysis suggested that multiple of the VDBP SNPs might increase the risk of osteoporosis in postmenopausal women [93]. VDBP is not the only one factor that can have influence on bone mineral density but rs7041 had significant association with BMD-L4 and a higher frequency of osteoporosis [94].

\subsubsection{Rheumatoid Arthritis}

A study by Yan et al. showed a significant correlation between RA and rs2282679 SNP [95]. Rs4588 and rs7041 are the main genetic factors that contribute to variations in 25(OH)D status as well as variations in VDBP levels [96]. This genetic effect might be connected to a novel pathogenic pathway that vitamin D takes part in [95]. 1,25(OH)2D3 may have inhibitory effect on osteoclasts formation that is induced by IL-22 in RA [97,98]. Substitution of amino acids in the different isoforms of VDBP, like 1S and 2 isoforms, differ from the $1 \mathrm{~F}$ isoform by post-translational glycosylation. The deglycosylated form of VDBP can promote activation of macrophages and osteoclasts [99,100]. The differentiation of osteoclasts is induced by macrophage colony-stimulating factor (M-CSF) and the receptor activator of nuclear factor- $\mathrm{KB}$ ligand (RANKL). The active form of 1,25(OH)2D3 binds to the VDBP and is transported to target organ or tissue by the blood circulation. Active 1,25(OH)2D3 binds to VDR and by enhancing RANKL secretion, it regulates the activity of osteoblasts [100].

\subsubsection{Ankylosing Spondylitis}

The study of Jung et al. showed that among VDBP variations (rs4752, rs222016, rs222020, rs3733359) there is an association with the development of peripheral arthritis or uveitis. The haplotype (AGGA) was protective from peripheral arthritis development, while the haplotype (GAAG) lowers the risk of uveitis. VDBP polymorphisms are associated with ankylosing spondylitis development that affects the axial spine, sacroiliac joints leading to bone formation and ankylosis [48].

\subsubsection{Asthma}

A study among Chinese population showed two common polymorphisms: rs7041 and rs4588. Further analysis showed that Gc2 is strongly associated with the risk of asthma but not with the plasma concentration of $25(\mathrm{OH}) \mathrm{D}$ among asthma patients. Gc1 might actually confer a protective effect. VDBP enhances the chemotactic activity of monocytes and neutrophils modulates Th2-mediated inflammation and influences the susceptibility to asthma [101,102]. A recent study among childhood Chinese patients showed that rs7041 and rs4588 Gc polymorphisms are significantly associated with lower risk of bronchial asthma [103]. Another study from Egyptian children and adolescents showed that rs4588 CA and AA genotypes were protective, while rs7041 GG genotype had significantly higher frequency among patients [104]. Among Kurdish population rs7041 GG genotype was corelated with increased risk of asthma progression [105].

\subsubsection{Chronic Obstructive Pulmonary Disease (COPD)}

In Icelandic COPD patients the association of Gc genotypes were examined. Results showed that Gc1F and Gc2 genotype have an effect on sputum production among patients and increase risk of developing COPD [106]. VDBP may be mediated by affecting on macrophage activation. Macrophages accumulate in the COPD patients lungs and can release neutrophil chemoattractants in case of activation [107]. Among Korean patients the GC2 variant was a significant risk factor for vitamin D deficiency which is mostly low among COPD patients and 1F-1S genotype was protective 
factor against deficiency of vitamin D [108]. High frequencies of the haplotypes in rs7041 and rs4588-GC1S/1S. High sputum VDBP levels in COPD stage I and II were observed only among GC1S/1S genotype. The results of this study might contribute to further exploring the use of VDBP as a COPD biomarker [109].

\subsubsection{Tuberculosis}

Vitamin D deficiency has already been associated with susceptibility to active tuberculosis-one of the leading cause of death in the world. Among Gujarati Asians, Gc2 genotype was associated with higher susceptibility to active tuberculosis but at the same time there was no such association among Rio and Cape Town population. This may be explained by the increased sun exposure in the Rio and Cape Town populations. Moreover, the number of Gc2 allele carriers among the Gujarati Asians is small, so this study might not detect fully correct associations $[107,110]$. Among Taiwanese population there was a strong correlation between GC1F and tuberculosis [111]. Another study showed no significant correlation between rs7041 and rs4588 polymorphism and susceptibility to tuberculosis [112].

\subsubsection{Coronary Artery Diseases (CAD)}

The study of Kiani's et al. in 2019 showed the associations of SNPs of VDR (rs1544410G>A) and those in VDBP (rs7041 T>G) as examined among a population of West Iran. Rs1544410 G>A was more frequent among CAD patients and was a strong risk factor for CAD. Rs7041 T>G gene polymorphism has a strong protective role against AMVC (Aortic and Mitral Valves Calcification) among this population in Iran. Also, a strong association of vitamin D deficiency, lipid profile and VDR rs1544410G $>$ A and VDBP rs7041 T>G gene polymorphisms might be the reason of an increased CAD risk among these patients [113]. Another study showed that both rs7041 and rs4588 polymorphisms are not associated to the prevalence and extent of CAD.

Table 2 summarizes the knowledge on the VDBP influence on diseases epidemiology.

Table 2. Vitamin D binding protein (VDBP) and human diseases.

\begin{tabular}{|c|c|c|c|}
\hline Disease & VDBP Influence & Mechanism & Reference \\
\hline \multicolumn{4}{|c|}{ Cancers } \\
\hline Breast cancer & $\begin{array}{c}\text { Gc2-2 genotype associated with decreased risk } \\
\text { of postmenopausal breast cancer }(\mathrm{n}=1402, \\
\text { control: } 2608) \\
\text { SNPs: rs17467825, rs2298850 and rs3755967 are } \\
\text { associated to the breast cancer risk }(\mathrm{n}=818, \\
\text { controls }=935) ; \\
\text { another study does not support an important } \\
\text { role of either calculated circulating free } \\
\text { 25(OH)D or circulating VDBP levels in breast } \\
\text { cancer risk among predominantly } \\
\text { premenopausal women; } \\
\text { (controls }=584)\end{array}$ & $\begin{array}{l}\text { The carcinogenic mechanism is } \\
\text { based on the potential to convert Gc } \\
\text { to GcMAF, which is a macrophage } \\
\text { activator. GcMAF may enhance } \\
\text { proapoptotic enzymes activity and } \\
\text { induce cell apoptosis via JNK1/2 } \\
\text { and p387 pathway-that may } \\
\text { inhibit cancer development }\end{array}$ & {$[51,54,114-116]$} \\
\hline Prostate cancer & $\begin{array}{l}\text { Decreased risk in of prostate cancer associated } \\
\text { with higher serum VDBP levels in men with } \\
\text { lower than median } 25(\mathrm{OH}) \mathrm{D} \text { status, where } \\
\text { elevated risk in men with higher than median } \\
25(\mathrm{OH}) \mathrm{D} \text { concentration }(\mathrm{n}=950 \text {, control }=964) \text {; } \\
\text { SNP: Rs2282679 in } G c \text { has no significant } \\
\text { correlation with non-aggressive and aggressive } \\
\text { prostate cancer }(\mathrm{n}=10,572 \text {, controls }=4975)\end{array}$ & $\begin{array}{l}\text { Extracellular concentrations of } \\
\text { VDBP and 25(OH)D result in an } \\
\text { upregulation of megalin-mediated } \\
\text { internalization of } \\
\text { SHBG-bound testosterone }\end{array}$ & {$[65,117]$} \\
\hline Pancreatic cancer & $\begin{array}{l}\text { Higher serum } 25(\mathrm{OH}) \mathrm{D} \text { and serum VDBP are } \\
\text { associated with higher pancreatic cancer risk } \\
(\mathrm{n}=234 \text {, control = 234) among Finnish men } \\
\text { population; } \\
\text { VDBP or 25(OH)D were not associated with } \\
\text { pancreatic cancer }(\mathrm{n}=295 \text {, two controls } \\
\mathrm{n}=590) ; \\
\text { rs2282679, rs7041 and rs } 4588 \text { found no } \\
\text { significant correlation with pancreas cancer }\end{array}$ & $\begin{array}{c}\text { Reducing free } 25(\mathrm{OH}) \mathrm{D} \text { by VDBP } \\
\text { decreases bioavailability; } \\
\text { high concentration of VDBP and } \\
\text { 25(OH)D could potentially displace } \\
\text { 1,25(OH)D with its } \\
\text { antitumorigenic properties }\end{array}$ & {$[64,70,71]$} \\
\hline
\end{tabular}


Table 2. Cont.

\begin{tabular}{|c|c|c|c|}
\hline Disease & VDBP Influence & Mechanism & Reference \\
\hline Lung cancer & $\begin{array}{l}\text { VDBP low serum concentration might be a } \\
\text { predictor of subsequent death from non-small } \\
\text { cell lung cancer ( } \mathrm{n}=148 \text { lung cancer patients, } \\
68 \text { patients with other intrathoracic tumors and } \\
33 \text { noncancer controls); } \\
\text { GC2-1f combination (TT-CA) has significant } \\
\text { and protective association with lung cancer } \\
\text { ( } \mathrm{n}=113 \text {, control }=113) ; \\
\text { Rs7041 in GC gene reduces the risk of } \\
\text { Non-Small Cell Lung Cancer risk }(\mathrm{n}=446, \\
\text { controls }=425)\end{array}$ & $\begin{array}{l}\text { Conversion of VDBP to GcMAF } \\
\text { may be reduced in malignancy due } \\
\text { to the action of } \\
\alpha-\mathrm{N} \text {-acetylogalactosaminidasa and } \\
\text { as a result it might lower } \\
\text { macrophage activation }\end{array}$ & {$[72,75,90]$} \\
\hline Colorectal cancer & $\begin{array}{l}\text { Rs7041 (TG/GG) significant association with } \\
\text { colorectal cancers among age } 60 \text { years old and } \\
\text { older }(\mathrm{n}=282 \text {, control }=113) ; \\
\text { Rs4588 (CA/AA) significant association with } \\
\text { cancer in males aged } 60 \text { years old or less } \\
\text { ( } \mathrm{n}=282 \text {, control }=113) ; \\
\text { Both: Gc/Rs7041 and CYP2R1/rs } 10741657 \\
\text { polymorphisms decreases the risk of colorectal } \\
\text { cancer about } 9-12 \%(\mathrm{n}=920 \text {, controls }=1743)\end{array}$ & & {$[74,76]$} \\
\hline Basal cell carcinoma & $\begin{array}{l}\text { SNP may affect skin carcinogenesis. Among } \\
\text { patients with rs7041 and rs4588 } 233 \text { of them } \\
\text { developed BCC and } 52.4 \% \text { among those } \\
\text { patients developed multiple BCCs }(\mathrm{n}=7983) \text {. } \\
\text { GC1s homozygotes had lower BCC risk. } \\
\text { Rs7041 was associated with BCC development } \\
\text { among the youngest group. }\end{array}$ & $\begin{array}{c}\text { SNPs may be associated with BCC } \\
\text { development among } \\
\text { younger patients }\end{array}$ & [77] \\
\hline Cutaneous Melanoma & $\begin{array}{l}\text { Association between VDBP rs12512631 and risk } \\
\text { of cutaneous melanoma among Spanish } \\
\text { population }(\mathrm{n}=530 \text {, controls }=314) ; \\
\text { No association between VDBP rs1155563 and } \\
\text { rs7041 and melanoma risk or prognosis } \\
(\mathrm{n}=305 \text {, controls }=370)\end{array}$ & $\begin{array}{l}\text { VDBP variants may influence on } \\
\text { vitamin synthesis and distribution }\end{array}$ & [78-80] \\
\hline Obesity & $\begin{array}{c}\text { Possible role of VDBP in the relation between } \\
\text { body fat mass and vitamin D metabolism } \\
\text { rs17467825 and its corresponding haplotype } \\
\text { GAA—strongest association in females; } \\
\text { VDBP has an influence on PFM (percentage of } \\
\text { fat mass), more significant associations are } \\
\text { more female-specific }\end{array}$ & A lipid-bound VDBP fraction & {$[47,88,89,118-122]$} \\
\hline Diabetes mellitus & $\begin{array}{l}\text { People with Gc1S-2 and 1S-1S had higher } \\
\text { fasting plasma insulin concentration than 1F-1F; } \\
\text { rs7041 (Glu/Glu-416) and rs } 4588 \text { (Lys/Lys-420) } \\
\text { variants of VDBP were higher in type } 2 \text { diabetic } \\
\text { comparing to control group }(\mathrm{n}=104, \\
\text { controls }=107)\end{array}$ & $\begin{array}{l}\text { Polymorphisms of VDBP might be } \\
\text { associated with insulin resistance in } \\
\text { Japanese population with normal } \\
\text { glucose tolerance. It might } \\
\text { contribute to type } 2 \\
\text { diabetes development. } \\
\text { VDBP affects glucose metabolism by } \\
\text { modulating the action of } \\
\text { metabolites of vitamin D; Vitamin D } \\
\text { stimulates synthesis of insulin, } \\
\text { effects on } \beta \text {-cells and protects them } \\
\text { against destruction by } \\
\text { inflammatory cytokines }\end{array}$ & {$[81-84,123-126]$} \\
\hline
\end{tabular}


Table 2. Cont.

\begin{tabular}{|c|c|c|c|}
\hline Disease & VDBP Influence & Mechanism & Reference \\
\hline Bone metabolism & $\begin{array}{c}\text { An inverse correlation between serum VDBP } \\
\text { levels and BMD; } \\
\text { A highly significant difference in } \\
\text { premenopausal bone fracture risk among } \\
\text { women with different VDBP phenotypes } \\
\text { (VDBP1-1>VDBP2-1>VDBP2-2); } \\
\text { SNPs in the VDBP gene might be associated } \\
\text { with BMD; } \\
\text { VDBP rs4701 is associated with lower BMD-L4 } \\
\text { and higher risk of osteoporosis; } \\
\text { multiple of the VDBP SNPs might increase the } \\
\text { risk of osteoporosis in postmenopausal women }\end{array}$ & $\begin{array}{l}\text { Phenotype of VDBP is mediated by } \\
\text { VDBP-MAF and } \\
\text { activation osteoclasts }\end{array}$ & {$[90,93,127-133]$} \\
\hline Rheumatoid arthritis & correlation between RA and rs2282679 SNP & $\begin{array}{l}\text { 1,25(OH)2D3 may have inhibitory } \\
\text { effect on osteoclasts formation that } \\
\text { is induced by IL-22 }\end{array}$ & {$[95,97]$} \\
\hline Asthma & $\begin{array}{l}\text { Upregulation of DBP expression in patients } \\
\text { with diphenyl-methane disocyanate } \\
\text { occupational asthma DBP SNPs rs } 4588 \text { and } \\
\text { rs7041 are associated with the risk of asthma } \\
\text { and the DBP1 allele might confer a } \\
\text { protective effect; } \\
\text { patients with GC2 (compared to GC1) } \\
\text { haplotype are more susceptible for the } \\
\text { development of asthma; } \\
\text { Gc1, Gc2 was significantly associated with the } \\
\text { risk of asthma ( } \mathrm{n}=467, \text { control = 288); } \\
\text { Rs7041 and rs4588 associated with increased } \\
\text { risk of bronchial asthma (n = 143, } \\
\text { controls = 143); } \\
\text { Rs4588 CA and AA genotypes had protective } \\
\text { effect, while rs7041 GG genotype had } \\
\text { significantly higher frequency among patients } \\
\text { diagnosed with asthma (n = 96, controls = 96) }\end{array}$ & $\begin{array}{l}\text { VDBP and enhancing the } \\
\text { chemotactic activity of monocytes } \\
\text { and neutrophils; VDBP modules } \\
\text { Th2-mediated inflammation and } \\
\text { influences the susceptibility } \\
\text { to asthma }\end{array}$ & [101-105] \\
\hline $\begin{array}{l}\text { Chronic obstructive } \\
\text { pulmonary disease }\end{array}$ & $\begin{array}{l}\text { GC1f and GC2 alleles may be linked to sputum } \\
\text { hypersecretion in COPD patients; } \\
\text { Gc2 protects against COPD }(\mathrm{n}=140, \\
\text { control = 480) } \\
\text { 1F-1S genotype was protective factor against } \\
\text { deficiency of vitamin D among Korean patients } \\
\qquad(\mathrm{n}=175) ; \\
\text { High frequencies of the haplotypes in rs7041 } \\
\text { and rs4588_-GC1S/1S among COPD patients } \\
(\mathrm{n}=233)\end{array}$ & $\begin{array}{l}\text { VDBP has the potential to influence } \\
\text { the respiratory function by } \\
\text { determining vitamin D } \\
\text { bioavailability and via direct effects } \\
\text { on innate cell function }\end{array}$ & {$[101,106,108,109]$} \\
\hline Tuberculosis & $\begin{array}{l}\text { VDBP2-2 phenotype strongly associated to } \\
\text { susceptibility to TB among Gujarati Asians } \\
\text { ( } \mathrm{n}=534 \text {, control }=400) ; \\
\text { Among Taiwan patients the GC1F carriers were } \\
\text { associated with tuberculosis }(\mathrm{n}=198, \\
\text { controls }=170)\end{array}$ & $\begin{array}{l}\text { Reduced ability of VDBP2 to } \\
\text { conversion VDBP to VDBP-MAF }\end{array}$ & {$[107,134]$} \\
\hline Coronary artery diseases & $\begin{array}{l}\text { A strong interaction between A allele VDR } \\
\text { rs1544410 and G allele of VDBP rs7041 genes in } \\
\text { a protective role; strong association between } \\
\text { vitamin D deficiency, lipid profile and the VDR } \\
\text { rs1544410G > A and rs7T41>G VDBP genes } \\
\text { polymorphisms }(\mathrm{n}=157, \text { control = 182) } \\
\text { No correlation between rs7041, rs4588 and } \\
\text { CAD }(\mathrm{n}=1080) .\end{array}$ & & {$[113,135]$} \\
\hline
\end{tabular}




\section{Conclusions}

VDBP and vitamin D have a profound impact on humans' health. Polymorphisms in VDBP gene can be a significant risk factor in many diseases, including cancers. SNPs genotyping is an easy procedure that may be useful to create a SNPs panel in the vitamin D biochemical pathway genes that are known risk factors in cancer and other chronic diseases. As a consequence, this analysis is of great importance to identify the group with the highest risk of incidence of these diseases and thereby contribute to preventive strategies or diagnosis of these illnesses at an early stage.

Author Contributions: Conceptualization, A.C. (Anna Cieślińska) and D.R., Data Curation, N.K. and R.G.; Writing-Original Draft Preparation, D.R., A.C. (Alicja Ciesielska), E.F., A.C. (Anna Cieślińska); Writing-Review \& Editing, H.S., J.P., E.K.; Visualization, E.F.; Supervision, A.C. (Anna Cieślińska). All authors have read and agreed to the published version of the manuscript.

Funding: This research received no external funding.

Conflicts of Interest: The authors declare no conflict of interest.

\section{References}

1. Fleet, J.C. The role of vitamin D in the endocrinology controlling calcium homeostasis. Mol. Cell. Endocrinol. 2017, 453, 36-45. [CrossRef] [PubMed]

2. Holick, M.F. Resurrection of vitamin D deficiency and rickets. J. Clin. Investig. 2006, 116, $2062-2072$. [CrossRef] [PubMed]

3. Almesri, N.; Das, N.S.; Ali, M.E.; Gumaa, K.; Giha, H.A. Independent associations of polymorphisms in vitamin D binding protein $(G C)$ and vitamin D receptor $(V D)$ genes with obesity and plasma 25OHD3 levels demonstrate sex dimorphism. Appl. Physiol. Nutr. Metab. 2016, 41, 345-353. [CrossRef] [PubMed]

4. Schmidt, D.R.; Holmstrom, S.R.; Fon Tacer, K.; Bookout, A.L.; Kliewer, S.A.; Mangelsdorf, D.J. Regulation of Bile Acid Synthesis by Fat-soluble Vitamins A and D. J. Biol. Chem. 2010, 285, 14486-14494. [CrossRef] [PubMed]

5. Fakhoury, H.M.A.; Kvietys, P.R.; AlKattan, W.; Anouti, F.A.; Elahi, M.A.; Karras, S.N.; Grant, W.B. Vitamin D and intestinal homeostasis: Barrier, microbiota, and immune modulation. J. Steroid Biochem. Mol. Biol. 2020, 200, 105663. [CrossRef] [PubMed]

6. Adams, J.S.; Rafison, B.; Witzel, S.; Reyes, R.E.; Shieh, A.; Chun, R.; Zavala, K.; Hewison, M.; Liu, P.T. Regulation of the extrarenal CYP27B1-hydroxylase. J. Steroid Biochem. Mol. Biol. 2014, 144, 22-27. [CrossRef]

7. Battault, S.; Whiting, S.J.; Peltier, S.L.; Sadrin, S.; Gerber, G.; Maixent, J.M. Vitamin D metabolism, functions and needs: From science to health claims. Eur. J. Nutr. 2013, 52, 429-441. [CrossRef]

8. Aktürk, T.; Turan, Y.; Tanik, N.; Karadağ, M.E.; Sacmaci, H.; Inan, L.E. Vitamin D, vitamin D binding protein, vitamin $\mathrm{D}$ receptor levels and cardiac dysautonomia in patients with multiple sclerosis: A cross-sectional study. Arq. Neuropsiquiatr. 2019, 77, 848-854. [CrossRef]

9. Haussler, M.R.; Haussler, C.A.; Whitfield, G.K.; Hsieh, J.-C.; Thompson, P.D.; Barthel, T.K.; Bartik, L.; Egan, J.B.; Wu, Y.; Kubicek, J.L.; et al. The nuclear vitamin D receptor controls the expression of genes encoding factors which feed the "Fountain of Youth" to mediate healthful aging. J. Steroid Biochem. Mol. Biol. 2010, 121, 88-97. [CrossRef]

10. Pludowski, P.; Holick, M.F.; Grant, W.B.; Konstantynowicz, J.; Mascarenhas, M.R.; Haq, A.; Povoroznyuk, V.; Balatska, N.; Barbosa, A.P.; Karonova, T.; et al. Vitamin D supplementation guidelines. J. Steroid Biochem. Mol. Biol. 2018, 175, 125-135. [CrossRef]

11. Al Mheid, I.; Quyyumi, A.A. Vitamin D and Cardiovascular Disease. J. Am. Coll. Cardiol. 2017, 70, 89-100. [CrossRef]

12. Jäpelt, R.B.; Jakobsen, J. Vitamin D in plants: A review of occurrence, analysis, and biosynthesis. Front. Plant Sci. 2013, 4. [CrossRef] [PubMed]

13. Kennel, K.A.; Drake, M.T.; Hurley, D.L. Vitamin D Deficiency in Adults: When to Test and How to Treat. Mayo Clin. Proc. 2010, 85, 752-758. [CrossRef] [PubMed]

14. Bikle, D.D. Vitamin D Metabolism, Mechanism of Action, and Clinical Applications. Chem. Biol. 2014, 21, 319-329. [CrossRef] 
15. Pike, J.W.; Meyer, M.B. The unsettled science of nonrenal calcitriol production and its clinical relevance. J. Clin. Investig. 2020, 130, 4519-4521. [CrossRef]

16. Garland, C.F.; Garland, F.C.; Gorham, E.D.; Lipkin, M.; Newmark, H.; Mohr, S.B.; Holick, M.F. The Role of Vitamin D in Cancer Prevention. Am. J. Public Health 2006, 96, 252-261. [CrossRef]

17. Gorham, E.D.; Garland, C.F.; Garland, F.C.; Grant, W.B.; Mohr, S.B.; Lipkin, M.; Newmark, H.L.; Giovannucci, E.; Wei, M.; Holick, M.F. Vitamin D and prevention of colorectal cancer. J. Steroid Biochem. Mol. Biol. 2005, 97, 179-194. [CrossRef] [PubMed]

18. Holick, M.F. The Vitamin D Epidemic and its Health Consequences. J. Nutr. 2005, 135, 2739 S-2748S. [CrossRef]

19. Holick, M.F. Vitamin D Deficiency. N. Engl. J. Med. 2007, 16, 266-281. [CrossRef]

20. Lappe, J.M.; Travers-Gustafson, D.; Davies, K.M.; Recker, R.R.; Heaney, R.P. Vitamin D and calcium supplementation reduces cancer risk: Results of a randomized trial. Am. J. Clin. Nutr. 2007, 85, 1586-1591. [CrossRef]

21. Liu, P.T. Toll-Like Receptor Triggering of a Vitamin D-Mediated Human Antimicrobial Response. Science 2006, 311, 1770-1773. [CrossRef] [PubMed]

22. Manousaki, D.; Richards, J.B. Low vitamin D levels as a risk factor for cancer. BMJ 2017, 359. [CrossRef] [PubMed]

23. Dimitrakopoulou, V.I.; Tsilidis, K.K.; Haycock, P.C.; Dimou, N.L.; Al-Dabhani, K.; Martin, R.M.; Lewis, S.J.; Gunter, M.J.; Mondul, A.; Shui, I.M.; et al. Circulating vitamin D concentration and risk of seven cancers: Mendelian randomisation study. BMJ 2017, 359. [CrossRef] [PubMed]

24. Skaaby, T.; Thuesen, B.H.; Linneberg, A. Vitamin D, Cardiovascular Disease and Risk Factors. In Ultraviolet Light in Human Health, Diseases and Environment; Ahmad, S.I., Ed.; Advances in Experimental Medicine and Biology; Springer International Publishing: Cham, Switzerland, 2017; pp. 221-230. ISBN 978-3-319-56017-5.

25. Kheiri, B.; Abdalla, A.; Osman, M.; Ahmed, S.; Hassan, M.; Bachuwa, G. Vitamin D deficiency and risk of cardiovascular diseases: A narrative review. Clin. Hypertens. 2018, 24, 9. [CrossRef] [PubMed]

26. Lucato, P.; Solmi, M.; Maggi, S.; Bertocco, A.; Bano, G.; Trevisan, C.; Manzato, E.; Sergi, G.; Schofield, P.; Kouidrat, Y.; et al. Low vitamin D levels increase the risk of type 2 diabetes in older adults: A systematic review and meta-analysis. Maturitas 2017, 100, 8-15. [CrossRef]

27. Bragazzi, N.L.; Watad, A.; Neumann, S.G.; Simon, M.; Brown, S.B.; Abu Much, A.; Harari, A.; Tiosano, S.; Amital, H.; Shoenfeld, Y. Vitamin D and rheumatoid arthritis: An ongoing mystery. Curr. Opin. Rheumatol. 2017, 29, 378-388. [CrossRef]

28. Hajjaj-Hassouni, N.; Mawani, N.; Allali, F.; Rkain, H.; Hassouni, K.; Hmamouchi, I.; Dougados, M. Evaluation of Vitamin D Status in Rheumatoid Arthritis and Its Association with Disease Activity across 15 Countries: "The COMORA Study". Available online: https://www.hindawi.com/journals/ijr/2017/5491676/ (accessed on 26 September 2020).

29. Huang, S.-J.; Wang, X.-H.; Liu, Z.-D.; Cao, W.-L.; Han, Y.; Ma, A.-G.; Xu, S.-F. Vitamin D deficiency and the risk of tuberculosis: A meta-analysis. Drug Des. Devel. Ther. 2016, 11, 91-102. [CrossRef]

30. Manson, J.E.; Cook, N.R.; Lee, I.-M.; Christen, W.; Bassuk, S.S.; Mora, S.; Gibson, H.; Gordon, D.; Copeland, T.; D'Agostino, D.; et al. Vitamin D Supplements and Prevention of Cancer and Cardiovascular Disease. N. Engl. J. Med. 2019, 380, 33-44. [CrossRef]

31. Keum, N.; Lee, D.H.; Greenwood, D.C.; Manson, J.E.; Giovannucci, E. Vitamin D supplementation and total cancer incidence and mortality: A meta-analysis of randomized controlled trials. Ann. Oncol. Off. J. Eur. Soc. Med. Oncol. 2019, 30, 733-743. [CrossRef]

32. Barbarawi, M.; Kheiri, B.; Zayed, Y.; Barbarawi, O.; Dhillon, H.; Swaid, B.; Yelangi, A.; Sundus, S.; Bachuwa, G.; Alkotob, M.L.; et al. Vitamin D Supplementation and Cardiovascular Disease Risks in More Than 83000 Individuals in 21 Randomized Clinical Trials: A Meta-analysis. JAMA Cardiol. 2019, 4, 765-776. [CrossRef]

33. Barsony, J.; Renyi, I.; McKoy, W. Subcellular Distribution of Normal and Mutant Vitamin D Receptors in Living Cells: STUDIES WITH A NOVEL FLUORESCENT LIGAND. J. Biol. Chem. 1997, 272, 5774-5782. [CrossRef]

34. Christakos, S.; Dhawan, P.; Verstuyf, A.; Verlinden, L.; Carmeliet, G. Vitamin D: Metabolism, Molecular Mechanism of Action, and Pleiotropic Effects. Physiol. Rev. 2015, 96, 365-408. [CrossRef] [PubMed] 
35. Ding, N.; Yu, R.T.; Subramaniam, N.; Sherman, M.H.; Wilson, C.; Rao, R.; Leblanc, M.; Coulter, S.; He, M.; Scott, C.; et al. A Vitamin D Receptor/SMAD Genomic Circuit Gates Hepatic Fibrotic Response. Cell 2013, 153, 601-613. [CrossRef]

36. Pike, J.W.; Meyer, M.B.; Benkusky, N.A.; Lee, S.M.; St. John, H.; Carlson, A.; Onal, M.; Shamsuzzaman, S. Genomic Determinants of Vitamin D-Regulated Gene Expression. Vitam. Horm. 2016, 100, 21-44. [CrossRef]

37. Keegan, R.-J.H.; Lu, Z.; Bogusz, J.M.; Williams, J.E.; Holick, M.F. Photobiology of vitamin D in mushrooms and its bioavailability in humans. Dermato-Endocrinology 2013, 5, 165-176. [CrossRef]

38. Holick, M.F. The Influence of Vitamin D on Bone Health across the Life Cycle. J. Nutr. 2005, 135, 2726S-2727S. [CrossRef] [PubMed]

39. Norman, A.W. From vitamin D to hormone D: Fundamentals of the vitamin D endocrine system essential for good health. Am. J. Clin. Nutr. 2008, 88, 491S-499S. [CrossRef] [PubMed]

40. Armas, L.A.G.; Hollis, B.W.; Heaney, R.P. Vitamin $\mathrm{D}_{2}$ Is Much Less Effective than Vitamin $\mathrm{D}_{3}$ in Humans. J. Clin. Endocrinol. Metab. 2004, 89, 5387-5391. [CrossRef]

41. Glendenning, P.; Chew, G.T.; Seymour, H.M.; Gillett, M.J.; Goldswain, P.R.; Inderjeeth, C.A.; Vasikaran, S.D.; Taranto, M.; Musk, A.A.; Fraser, W.D. Serum 25-hydroxyvitamin D levels in vitamin D-insufficient hip fracture patients after supplementation with ergocalciferol and cholecalciferol. Bone 2009, 45, 870-875. [CrossRef]

42. Romagnoli, E.; Mascia, M.L.; Cipriani, C.; Fassino, V.; Mazzei, F.; D’Erasmo, E.; Carnevale, V.; Scillitani, A.; Minisola, S. Short and Long-Term Variations in Serum Calciotropic Hormones after a Single Very Large Dose of Ergocalciferol (Vitamin D2) or Cholecalciferol (Vitamin D3) in the Elderly. J. Clin. Endocrinol. Metab. 2008, 93, 3015-3020. [CrossRef]

43. Trang, H.M.; Cole, D.E.; Rubin, L.A.; Pierratos, A.; Siu, S.; Vieth, R. Evidence that vitamin D3 increases serum 25-hydroxyvitamin D more efficiently than does vitamin D2. Am. J. Clin. Nutr. 1998, 68, 854-858. [CrossRef] [PubMed]

44. Hirschfeld, J. Immune-electrophoretic demonstration of qualitative differences in human sera and their relation to the haptoglobins. Acta Pathol. Microbiol. Scand. 2009, 47, 160-168. [CrossRef]

45. Cooke, N.E.; Haddad, J.G. Vitamin D Binding Protein (Gc-Globulin)*. Endocr. Rev. 1989, 10, $294-307$. [CrossRef] [PubMed]

46. Song, Y.-H.; Naumova, A.K.; Liebhaber, S.A.; Cooke, N.E. Physical and Meiotic Mapping of the Region of Human Chromosome 4q11-q13 Encompassing the Vitamin D Binding Protein DBP/Gc-Globulin and Albumin Multigene Cluster. Genome Res. 1999, 9, 581-587. [PubMed]

47. Speeckaert, M.; Huang, G.; Delanghe, J.R.; Taes, Y.E.C. Biological and clinical aspects of the vitamin D binding protein (Gc-globulin) and its polymorphism. Clin. Chim. Acta 2006, 372, 33-42. [CrossRef]

48. Jung, K.-H.; Kim, T.-H.; Sheen, D.-H.; Lim, M.-K.; Lee, S.-K.; Kim, J.-Y.; Park, H.; Chae, S.-C.; Shim, S.-C. Associations of Vitamin D Binding Protein Gene Polymorphisms with the Development of Peripheral Arthritis and Uveitis in Ankylosing Spondylitis. J. Rheumatol. 2011, 38, 2224-2229. [CrossRef]

49. Metcalf, J.P.; Thompson, A.B.; Gossman, G.L.; Nelson, K.J.; Koyama, S.; Rennard, S.I.; Robbins, R.A. GcGlobulin Functions as a Cochemotaxin in the Lower Respiratory Tract: A Potential Mechanism for Lung Neutrophil Recruitment in Cigarette Smokers. Am. Rev. Respir. Dis. 1991, 143, 844-849. [CrossRef]

50. Haldar, D.; Agrawal, N.; Patel, S.; Kambale, P.R.; Arora, K.; Sharma, A.; Tripathi, M.; Batra, A.; Kabi, B.C. Association of VDBP and CYP2R1 gene polymorphisms with vitamin D status in women with polycystic ovarian syndrome: A north Indian study. Eur. J. Nutr. 2018, 57, 703-711. [CrossRef]

51. Abbas, S.; Linseisen, J.; Slanger, T.; Kropp, S.; Mutschelknauss, E.J.; Flesch-Janys, D.; Chang-Claude, J. The Gc2 Allele of the Vitamin D Binding Protein Is Associated with a Decreased Postmenopausal Breast Cancer Risk, Independent of the Vitamin D Status. Cancer Epidemiol. Biomark. Prev. 2008, 17, 1339-1343. [CrossRef]

52. Arnaud, J.; Constans, J. Affinity differences for vitamin D metabolites associated with the genetic isoforms of the human serum carrier protein (DBP). Hum. Genet. 1993, 92. [CrossRef]

53. Braun, A.; Bichlmaier, R.; Cleve, H. Molecular analysis of the gene for the human vitamin-D-binding protein (group-specific component): Allelic differences of the common genetic GC types. Hum. Genet. 1992, 89. [CrossRef] [PubMed] 
54. Yamamoto, N.; Homma, S. Vitamin D3 binding protein (group-specific component) is a precursor for the macrophage-activating signal factor from lysophosphatidylcholine-treated lymphocytes. Proc. Natl. Acad. Sci. USA 1991, 88, 8539-8543. [CrossRef] [PubMed]

55. Wang, J.; Eliassen, A.H.; Spiegelman, D.; Willett, W.C.; Hankinson, S.E. Plasma free 25-hydroxyvitamin D, vitamin D binding protein, and risk of breast cancer in the Nurses' Health Study II. Cancer Causes Control 2014, 25, 819-827. [CrossRef] [PubMed]

56. Kamboh, M.I.; Ferrell, R.E. Ethnic variation in vitamin D-binding protein (GC): A review of isoelectric focusing studies in human populations. Hum. Genet. 1986, 72, 281-293. [CrossRef]

57. Perna, L.; Felix, J.F.; Breitling, L.P.; Haug, U.; Raum, E.; Burwinkel, B.; Schöttker, B.; Brenner, H. Genetic Variations in the Vitamin D Binding Protein and Season-Specific Levels of Vitamin D Among Older Adults. Epidemiology 2013, 24, 104-109. [CrossRef]

58. Nagasawa, H.; Uto, Y.; Sasaki, H.; Okamura, N.; Murakami, A.; Kubo, S.; Kirk, K.L.; Hori, H. Gc protein (vitamin D-binding protein): Gc genotyping and GcMAF precursor activity. Anticancer Res. 2005, 25, 3689-3695.

59. Saburi, E.; Saburi, A.; Ghanei, M. Promising role for Gc-MAF in cancer immunotherapy: From bench to bedside. Casp. J. Intern. Med. 2017, 8. [CrossRef]

60. Păduraru, D.N.; Bouariu, A.; Ion, D.; Andronic, O.; Dumitrașcu, M.C.; Bolocan, A. Considerations Regarding GCMAF Treatement in Breast Cancer. Romanian Biotechnol. Lett. 2019, 24, 851-855. [CrossRef]

61. Francis, I.; AlAbdali, N.; Kapila, K.; John, B.; Al-Temaimi, R.A. Vitamin D pathway related polymorphisms and vitamin D receptor expression in breast cancer. Int. J. Vitam. Nutr. Res. Int. Z. Vitam. Ernahrungsforschung J. Int. Vitaminol. Nutr. 2019, 1-9. [CrossRef]

62. McDonnell, S.L.; Baggerly, C.A.; French, C.B.; Baggerly, L.L.; Garland, C.F.; Gorham, E.D.; Hollis, B.W.; Trump, D.L.; Lappe, J.M. Breast cancer risk markedly lower with serum 25-hydroxyvitamin D concentrations $\geq 60$ vs $<20 \mathrm{ng} / \mathrm{ml}(150$ vs $50 \mathrm{nmol} / \mathrm{L})$ : Pooled analysis of two randomized trials and a prospective cohort. PLoS ONE 2018, 13, e0199265. [CrossRef]

63. McDonnell, S.L.; Baggerly, C.; French, C.B.; Baggerly, L.L.; Garland, C.F.; Gorham, E.D.; Lappe, J.M.; Heaney, R.P. Serum 25-Hydroxyvitamin D Concentrations $\geq 40 \mathrm{ng} / \mathrm{ml}$ Are Associated with $>65 \%$ Lower Cancer Risk: Pooled Analysis of Randomized Trial and Prospective Cohort Study. PLoS ONE 2016, 11, e0152441. [CrossRef] [PubMed]

64. Weinstein, S.J.; Stolzenberg-Solomon, R.Z.; Kopp, W.; Rager, H.; Virtamo, J.; Albanes, D. Impact of Circulating Vitamin D Binding Protein Levels on the Association between 25-Hydroxyvitamin D and Pancreatic Cancer Risk: A Nested Case-Control Study. Cancer Res. 2012, 72, 1190-1198. [CrossRef]

65. Mondul, A.M.; Shui, I.M.; Yu, K.; Travis, R.C.; Stevens, V.L.; Campa, D.; Schumacher, F.R.; Ziegler, R.G.; Bueno-de-Mesquita, H.B.; Berndt, S.; et al. Genetic Variation in the Vitamin D Pathway in Relation to Risk of Prostate Cancer-Results from Breast and Prostate Cancer Cohort Consortium (BPC3). Cancer Epidemiol. Biomark. Prev. Publ. Am. Assoc. Cancer Res. Cosponsored Am. Soc. Prev. Oncol. 2013, 22, 688-696. [CrossRef] [PubMed]

66. Gao, J.; Wei, W.; Wang, G.; Zhou, H.; Fu, Y.; Liu, N. Circulating vitamin D concentration and risk of prostate cancer: A dose-response meta-analysis of prospective studies. Ther. Clin. Risk Manag. 2018, 14, 95-104. [CrossRef]

67. Liu, Y.; Wang, X.; Sun, X.; Lu, S.; Liu, S. Vitamin intake and pancreatic cancer risk reduction: A meta-analysis of observational studies. Medicine (Baltimore) 2018, 97, e0114. [CrossRef]

68. Wilson, K.M.; Shui, I.M.; Mucci, L.A.; Giovannucci, E. Calcium and phosphorus intake and prostate cancer risk: A 24-y follow-up study. Am. J. Clin. Nutr. 2015, 101, 173-183. [CrossRef] [PubMed]

69. Batai, K.; Murphy, A.B.; Ruden, M.; Newsome, J.; Shah, E.; Dixon, M.A.; Jacobs, E.T.; Hollowell, C.M.P.; Ahaghotu, C.; Kittles, R.A. Race and BMI modify associations of calcium and vitamin D intake with prostate cancer. BMC Cancer 2017, 17, 64. [CrossRef] [PubMed]

70. $\quad$ Piper, M.R.; Freedman, D.M.; Robien, K.; Kopp, W.; Rager, H.; Horst, R.L.; Stolzenberg-Solomon, R.Z. Vitamin D-binding protein and pancreatic cancer: A nested case-control study. Am. J. Clin. Nutr. 2015, 101, 1206-1215. [CrossRef]

71. Tagliabue, E.; Raimondi, S.; Gandini, S. Meta-analysis of Vitamin D-Binding Protein and Cancer Risk. Cancer Epidemiol. Biomark. Prev. 2015, 24, 1758-1765. [CrossRef] 
72. Turner, A.M.; McGowan, L.; Millen, A.; Rajesh, P.; Webster, C.; Langman, G.; Rock, G.; Tachibana, I.; Tomlinson, M.G.; Berditchevski, F.; et al. Circulating DBP level and prognosis in operated lung cancer: An exploration of pathophysiology. Eur. Respir. J. 2013, 41, 410-416. [CrossRef]

73. Mick, P.J.; Peng, S.A.; Loftus, J.P. Serum Vitamin D Metabolites and CXCL10 Concentrations Associate with Survival in Dogs with Immune Mediated Disease. Front. Vet. Sci. 2019, 6. [CrossRef] [PubMed]

74. Maneechay, W.; Boonpipattanapong, T.; Kanngurn, S.; Puttawibul, P.; Geater, S.L.; Sangkhathat, S. Single Nucleotide Polymorphisms in the Gc Gene for Vitamin D Binding Protein in Common Cancers in Thailand. Asian Pac. J. Cancer Prev. 2015, 16, 3339-3344. [CrossRef] [PubMed]

75. Wu, X.; Cheng, J.; Yang, K. Vitamin D-Related Gene Polymorphisms, Plasma 25-Hydroxy-Vitamin D, Cigarette Smoke and Non-Small Cell Lung Cancer (NSCLC) Risk. Int. J. Mol. Sci. 2016, 17, 1597. [CrossRef] [PubMed]

76. Kopp, T.I.; Vogel, U.; Andersen, V. Associations between common polymorphisms in CYP2R1 and GC, Vitamin D intake and risk of colorectal cancer in a prospective case-cohort study in Danes. PLoS ONE 2020, 15, e0228635. [CrossRef]

77. Flohil, S.C.; Vries, E.D.; Meurs, J.B.J.V.; Fang, Y.; Stricker, B.H.C.; Uitterlinden, A.G.; Nijsten, T. Vitamin D-binding protein polymorphisms are not associated with development of (multiple) basal cell carcinomas. Exp. Dermatol. 2010, 19, 1103-1105. [CrossRef] [PubMed]

78. Peña-Chilet, M.; Ibarrola-Villava, M.; Martin-González, M.; Feito, M.; Gomez-Fernandez, C.; Planelles, D.; Carretero, G.; Lluch, A.; Nagore, E.; Ribas, G. rs12512631 on the Group Specific Complement (Vitamin D-Binding Protein GC) Implicated in Melanoma Susceptibility. PLoS ONE 2013, 8, e59607. [CrossRef]

79. Yin, J.; Liu, H.; Yi, X.; Wu, W.; Amos, C.I.; Fang, S.; Lee, J.E.; Han, J.; Wei, Q. Genetic Variants in the Vitamin D Pathway Genes VDBP and RXRA Modulate Cutaneous Melanoma Disease-Specific Survival. Pigment Cell Melanoma Res. 2016, 29, 176-185. [CrossRef]

80. Schäfer, A.; Emmert, S.; Kruppa, J.; Schubert, S.; Tzvetkov, M.; Mössner, R.; Reich, K.; Berking, C.; Volkenandt, M.; Pföhler, C.; et al. No association of vitamin D metabolism-related polymorphisms and melanoma risk as well as melanoma prognosis: A case-control study. Arch. Dermatol. Res. 2012, 304, 353-361. [CrossRef]

81. Hirai, M.; Suzuki, S.; Hinokio, Y.; Chiba, M.; Kasuga, S.; Hirai, A.; Toyota, T. Group specific component protein genotype is associated with NIDDM in Japan. Diabetologia 1998, 41, 742-743. [CrossRef]

82. Hirai, M.; Suzuki, S.; Hinokio, Y.; Hirai, A.; Chiba, M.; Akai, H.; Suzuki, C.; Toyota, T. Variations in Vitamin D-Binding Protein (Group-Specific Component Protein) Are Associated with Fasting Plasma Insulin Levels in Japanese with Normal Glucose Tolerance. J. Clin. Endocrinol. Metab. 2000, 85, 1951-1953. [CrossRef]

83. Sandler, S.; Buschard, K.; Bendtzen, K. Effects of 1,25-dihydroxyvitamin D3 and the analogues MC903 and KH1060 on interleukin-1 beta-induced inhibition of rat pancreatic islet beta-cell function in vitro. Immunol. Lett. 1994, 41, 73-77. [CrossRef]

84. Rahman, M.M.; Hosen, M.B.; Faruk, M.O.; Hasan, M.M.; Kabir, Y.; Howlader, M.Z.H. Association of vitamin D and vitamin D binding protein (DBP) gene polymorphism with susceptibility of type 2 diabetes mellitus in Bangladesh. Gene 2017, 636, 42-47. [CrossRef]

85. Pittas, A.G.; Dawson-Hughes, B.; Sheehan, P.; Ware, J.H.; Knowler, W.C.; Aroda, V.R.; Brodsky, I.; Ceglia, L.; Chadha, C.; Chatterjee, R.; et al. Vitamin D Supplementation and Prevention of Type 2 Diabetes. N. Engl. J. Med. 2019, 381, 520-530. [CrossRef]

86. Pani, M.A.; Regulla, K.; Segni, M.; Hofmann, S.; Fner, M.H.; Pasquino, A.M.; Usadel, K.-H.; Badenhoop, K. A Polymorphism within the Vitamin D-Binding Protein Gene Is Associated with Graves' Disease but Not with Hashimoto's Thyroiditis. J. Clin. Endocrinol. Metab. 2002, 87, 2564-2567. [CrossRef]

87. Kurylowicz, A.; Ramos-Lopez, E.; Bednarczuk, T.; Badenhoop, K. Vitamin D-Binding Protein (DBP) Gene Polymorphism is Associated with Graves' Disease and the Vitamin D Status in a Polish Population Study. Exp. Clin. Endocrinol. Diabetes 2006, 114, 329-335. [CrossRef]

88. Jiang, H.; Xiong, D.-H.; Guo, Y.-F.; Shen, H.; Xiao, P.; Yang, F.; Chen, Y.; Zhang, F.; Recker, R.R.; Deng, H.-W. Association analysis of vitamin D-binding protein gene polymorphisms with variations of obesity-related traits in Caucasian nuclear families. Int. J. Obes. 2007, 31, 1319-1324. [CrossRef] [PubMed]

89. Wortsman, J.; Matsuoka, L.Y.; Chen, T.C.; Lu, Z.; Holick, M.F. Decreased bioavailability of vitamin D in obesity. Am. J. Clin. Nutr. 2000, 72, 690-693. [CrossRef] [PubMed] 
90. Powe, C.E.; Ricciardi, C.; Berg, A.H.; Erdenesanaa, D.; Collerone, G.; Ankers, E.; Wenger, J.; Karumanchi, S.A.; Thadhani, R.; Bhan, I. Vitamin D-binding protein modifies the vitamin D-bone mineral density relationship. J. Bone Miner. Res. 2011, 26, 1609-1616. [CrossRef]

91. Aloia, J.; Mikhail, M.; Dhaliwal, R.; Shieh, A.; Usera, G.; Stolberg, A.; Ragolia, L.; Islam, S. Free 25(OH)D and the Vitamin D Paradox in African Americans. J. Clin. Endocrinol. Metab. 2015, 100, 3356-3363. [CrossRef]

92. Martínez-Aguilar, M.M.; Aparicio-Bautista, D.I.; Ramírez-Salazar, E.G.; Reyes-Grajeda, J.P.; De la Cruz-Montoya, A.H.; Antuna-Puente, B.; Hidalgo-Bravo, A.; Rivera-Paredez, B.; Ramírez-Palacios, P.; Quiterio, M.; et al. Serum Proteomic Analysis Reveals Vitamin D-Binding Protein (VDBP) as a Potential Biomarker for Low Bone Mineral Density in Mexican Postmenopausal Women. Nutrients 2019, 11, 2853. [CrossRef]

93. Ezura, Y.; Nakajima, T.; Kajita, M.; Ishida, R.; Inoue, S.; Yoshida, H.; Suzuki, T.; Shiraki, M.; Hosoi, T.; Orimo, H.; et al. Association of Molecular Variants, Haplotypes, and Linkage Disequilibrium Within the Human Vitamin D-Binding Protein (DBP) Gene With Postmenopausal Bone Mineral Density. J. Bone Miner. Res. 2003, 18, 1642-1649. [CrossRef] [PubMed]

94. Sahmoud, S.; Ibrahim, M.S.; Toraih, E.A.; Kamel, N.; Fawzy, M.S.; Elfiky, S. Association of VDBP rs4701 Variant, but not VDR/RXR- $\alpha$ Over-Expression with BoneMineral Density in Pediatric Well-Chelated $\beta$-Thalassemia Patients. Mediterr. J. Hematol. Infect. Dis. 2020, 12, e2020037. [CrossRef] [PubMed]

95. Yan, X.; Zhao, Y.; Pan, J.; Fang, K.; Wang, Y.; Li, Z.; Chang, X. Vitamin D-binding protein (group-specific component) has decreased expression in rheumatoid arthritis. Clin. Exp. Rheumatol. 2012, 30, 525-533.

96. Brink, M.; Johansson, L.; Nygren, E.; Ärlestig, L.; Hultdin, J.; Rantapää-Dahlqvist, S. Vitamin D in individuals before onset of rheumatoid arthritis-Relation to vitamin D binding protein and its associated genetic variants. BMC Rheumatol. 2018, 2, 26. [CrossRef]

97. Haneul, K.; Seungye, B.; Seung-Min, H.; Jaeseon, L.; Min, J.S.; Jennifer, L.; Mi-La, C.; Seung-Ki, K.; Sung-Hwan, P. 1,25-dihydroxy Vitamin D3 and Interleukin-6 Blockade Synergistically Regulate Rheumatoid Arthritis by Suppressing Interleukin-17 Production and Osteoclastogenesis. J. Korean Med. Sci. 2020, 35. [CrossRef]

98. Zarei, A.; Morovat, A.; Javaid, K.; Brown, C.P. Vitamin D receptor expression in human bone tissue and dose-dependent activation in resorbing osteoclasts. Bone Res. 2016, 4, 1-10. [CrossRef]

99. Orhan, C.; Seyhan, B.; Baykara, O.; Yildiz, M.; Kasapcopur, O.; Buyru, N. Vitamin D binding protein genotype frequency in familial Mediterranean fever patients. Scand. J. Rheumatol. 2020, 1-5. [CrossRef]

100. Gu, J.; Tong, X.; Chen, Y.; Zhang, C.; Ma, T.; Li, S.; Min, W.; Yuan, Y.; Liu, X.; Bian, J.; et al. Vitamin D Inhibition of TRPV5 Expression During Osteoclast Differentiation. Int. J. Endocrinol. Metab. 2019, 17. [CrossRef] [PubMed]

101. Laufs, J.; Andrason, H.; Sigvaldason, A.; Halapi, E.; Thorsteinsson, L.; Jónassen, K.; Söebech, E.; Gislason, T.; Gulcher, J.R.; Stefansson, K.; et al. Association of Vitamin D Binding Protein Variants with Chronic Mucus Hypersecretion in Iceland. Am. J. PharmacoGenomics 2004, 4, 63-68. [CrossRef] [PubMed]

102. Li, F.; Jiang, L.; Willis-Owen, S.A.; Zhang, Y.; Gao, J. Vitamin D binding protein variants associate with asthma susceptibility in the Chinese han population. BMC Med. Genet. 2011, 12, 103. [CrossRef]

103. Zhang, Y.; Wang, Z.; Ma, T. Associations of Genetic Polymorphisms Relevant to Metabolic Pathway of Vitamin D3 with Development and Prognosis of Childhood Bronchial Asthma. DNA Cell Biol. 2017. [CrossRef] [PubMed]

104. Fawzy, M.S.; Elgazzaz, M.G.; Ibrahim, A.; Hussein, M.H.; Khashana, M.S.; Toraih, E.A. Association of group-specific component exon 11 polymorphisms with bronchial asthma in children and adolescents. Scand. J. Immunol. 2019, 89, e12740. [CrossRef] [PubMed]

105. Nasiri-Kalmarzi, R.; Abdi, M.; Hosseini, J.; Tavana, S.; Mokarizadeh, A.; Rahbari, R. Association of vitamin D genetic pathway with asthma susceptibility in the Kurdish population. J. Clin. Lab. Anal. 2020, 34, e23039. [CrossRef] [PubMed]

106. Wood, A.M.; Bassford, C.; Webster, D.; Newby, P.; Rajesh, P.; Stockley, R.A.; Thickett, D.R. Vitamin D-binding protein contributes to COPD by activation of alveolar macrophages. Thorax 2011, 66, 205-210. [CrossRef] [PubMed]

107. Martineau, A.R.; Leandro, A.C.C.S.; Anderson, S.T.; Newton, S.M.; Wilkinson, K.A.; Nicol, M.P.; Pienaar, S.M.; Skolimowska, K.H.; Rocha, M.A.; Rolla, V.C.; et al. Association between Gc genotype and susceptibility to TB is dependent on vitamin D status. Eur. Respir. J. 2010, 35, 1106-1112. [CrossRef] 
108. Park, Y.; Kim, Y.S.; Kang, Y.A.; Shin, J.H.; Oh, Y.M.; Seo, J.B.; Jung, J.Y.; Lee, S.D. Relationship between Vitamin D-Binding Protein Polymorphisms and Blood Vitamin D Level in Korean Patients with COPD. Available online: https://www.dovepress.com/relationship-between-vitamin-d-binding-protein-polymorphisms-andblood-peer-reviewed-article-COPD (accessed on 24 September 2020).

109. Gao, J.; Törölä, T.; Li, C.-X.; Ohlmeier, S.; Toljamo, T.; Nieminen, P.; Hattori, N.; Pulkkinen, V.; Iwamoto, H.; Mazur, W. Sputum Vitamin D Binding Protein (VDBP) GC1S/1S Genotype Predicts Airway Obstruction: A Prospective Study in Smokers with COPD. Available online: https://www.dovepress.com/sputum-vitamind-binding-protein-vdbp-gc1s1s-genotype-predicts-airway--peer-reviewed-article-COPD (accessed on 24 September 2020).

110. Brighenti, S.; Bergman, P.; Martineau, A.R. Vitamin D and tuberculosis: Where next? J. Intern. Med. 2018, 284, 145-162. [CrossRef]

111. Lee, S.-W.; Chuang, T.-Y.; Huang, H.-H.; Liu, C.-W.; Kao, Y.-H.; Wu, L.S.-H. VDR and VDBP genes polymorphisms associated with susceptibility to tuberculosis in a Han Taiwanese population. J. Microbiol. Immunol. Infect. 2016, 49, 783-787. [CrossRef]

112. Junaid, K.; Rehman, A.; Jolliffe, D.A.; Saeed, T.; Wood, K.; Martineau, A.R. Vitamin D deficiency associates with susceptibility to tuberculosis in Pakistan, but polymorphisms in VDR, DBP and CYP2R1 do not. BMC Pulm. Med. 2016, 16, 73. [CrossRef]

113. Kiani, A.; Mohamadi-Nori, E.; Vaisi-Raygani, A.; Tanhapour, M.; Elahi-Rad, S.; Bahrehmand, F.; Rahimi, Z.; Pourmotabbed, T. Vitamin D-binding protein and vitamin D receptor genotypes and 25-hydroxyvitamin D levels are associated with development of aortic and mitral valve calcification and coronary artery diseases. Mol. Biol. Rep. 2019, 46, 5225-5236. [CrossRef]

114. Bouillon, R.; Schuit, F.; Antonio, L.; Rastinejad, F. Vitamin D Binding Protein: A Historic Overview. Front. Endocrinol. 2020, 10, 910. [CrossRef]

115. Chen, F.; Zhu, Z.; van Duijnhoven, F.J.B.; Dong, M.; Qian, Y.; Yu, H.; Yang, J.; Cui, L.; Han, R.; Su, J.; et al. Genetic Variants in Group-Specific Component (GC) Gene Are Associated with Breast Cancer Risk among Chinese Women. Available online: https://www.hindawi.com/journals/bmri/2019/3295781/ (accessed on 23 September 2020).

116. Maalmi, H.; Walter, V.; Jansen, L.; Chang-Claude, J.; Owen, R.W.; Ulrich, A.; Schöttker, B.; Hoffmeister, M.; Brenner, H. Relationship of very low serum 25-hydroxyvitamin D3 levels with long-term survival in a large cohort of colorectal cancer patients from Germany. Eur. J. Epidemiol. 2017, 32, 961-971. [CrossRef] [PubMed]

117. Weinstein, S.J.; Mondul, A.M.; Kopp, W.; Rager, H.; Virtamo, J.; Albanes, D. Circulating 25-hydroxyvitamin D, vitamin D-binding protein and risk of prostate cancer. Int. J. Cancer 2013, 132, 2940-2947. [CrossRef] [PubMed]

118. Speeckaert, M.M.; Taes, Y.E.; De Buyzere, M.L.; Christophe, A.B.; Kaufman, J.-M.; Delanghe, J.R. Investigation of the potential association of vitamin D binding protein with lipoproteins. Ann. Clin. Biochem. 2010, 47, 143-150. [CrossRef]

119. Bolland, M.J.; Grey, A.B.; Ames, R.W.; Horne, A.M.; Mason, B.H.; Wattie, D.J.; Gamble, G.D.; Bouillon, R.; Reid, I.R. Age-, gender-, and weight-related effects on levels of 25-hydroxyvitamin D are not mediated by vitamin D binding protein. Clin. Endocrinol. 2007, 67, 259-264. [CrossRef] [PubMed]

120. Winters, S.J.; Chennubhatla, R.; Wang, C.; Miller, J.J. Influence of obesity on vitamin D-binding protein and 25-hydroxy vitamin D levels in African American and white women. Metabolism 2009, 58, 438-442. [CrossRef]

121. Fang, Y.; van Meurs, J.B.J.; d'Alesio, A.; Jhamai, M.; Zhao, H.; Rivadeneira, F.; Hofman, A.; van Leeuwen, J.P.T.; Jehan, F.; Pols, H.A.P.; et al. Promoter and 3'-Untranslated-Region Haplotypes in the Vitamin D Receptor Gene Predispose to Osteoporotic Fracture: The Rotterdam Study. Am. J. Hum. Genet. 2005, 77, 807-823. [CrossRef]

122. Fang, Y.; van Meurs, J.B.J.; Rivadeneira, F.; van Schoor, N.M.; van Leeuwen, J.P.T.; Lips, P.; Pols, H.A.P.; Uitterlinden, A.G. Vitamin D Receptor Gene Haplotype Is Associated with Body Height and Bone Size. J. Clin. Endocrinol. Metab. 2007, 92, 1491-1501. [CrossRef]

123. Blanton, D.; Han, Z.; Bierschenk, L.; Linga-Reddy, M.V.P.; Wang, H.; Clare-Salzler, M.; Haller, M.; Schatz, D.; Myhr, C.; She, J.-X.; et al. Reduced Serum Vitamin D-Binding Protein Levels Are Associated with Type 1 Diabetes. Diabetes 2011, 60, 2566-2570. [CrossRef] 
124. Khan, H.; Qureshi, A.M.; Murad, S. Vitamin D binding protein gene variants rs4588 and rs7041 and low serum concentration of 25-hydroxy $(\mathrm{OH})$ vitamin D3 in type-2 diabetes patients: A pilot study. Sci. Lett. 2015, 3, 39-41.

125. Ongagna, J.C.; Kaltenbacher, M.C.; Sapin, R.; Pinget, M.; Belcourt, A. The HLA-DQB alleles and amino acid variants of the vitamin D-binding protein in diabetic patients in Alsace. Clin. Biochem. 2001, 34, 59-63. [CrossRef]

126. Ongagna, J.C.; Pinget, M.; Belcourt, A. Vitamin D-binding protein gene polymorphism association with IA-2 autoantibodies in type 1 diabetes. Clin. Biochem. 2005, 38, 415-419. [CrossRef]

127. Xu, X.-H.; Xiong, D.-H.; Liu, X.-G.; Guo, Y.; Chen, Y.; Zhao, J.; Recker, R.R.; Deng, H.-W. Association analyses of vitamin D-binding protein gene with compression strength index variation in Caucasian nuclear families. Osteoporos. Int. 2010, 21, 99-107. [CrossRef] [PubMed]

128. Braun, A.; Bichlmaier, R.; Muller, B.; Cleve, H. Molecular evaluation of an Alu repeat including a polymorphic variable poly (dA) (AluVpA) in the vitamin D binding protein (DBP) gene. Hum. Genet. 1993, 90. [CrossRef] [PubMed]

129. Chupeerach, C.; Tungtrongchitr, A.; Phonrat, B.; Schweigert, F.J.; Tungtrongchitr, R.; Preutthipan, S. Association of Thr420Lys polymorphism in DBP gene with fat-soluble vitamins and low radial bone mineral density in postmenopausal Thai women. Biomark. Med. 2012, 6, 103-108. [CrossRef] [PubMed]

130. Papiha, S.S.; Allcroft, L.C.; Kanan, R.M.; Francis, R.M.; Datta, H.K. Vitamin D Binding Protein Gene in Male Osteoporosis: Association of Plasma DBP and Bone Mineral Density with (TAAA)n-Alu Polymorphism in DBP. Calcif. Tissue Int. 1999, 65, 262-266. [CrossRef]

131. Eichner, J.E.; Cauley, J.A.; Ferrell, R.E.; Cummings, S.R.; Kuller, L.H.; Vogler, G.P. Genetic variation in two bone-related proteins: Is there an association with bone mineral density or skeletal size in postmenopausal women?: Variation in Bone-Related Proteins in Women. Genet. Epidemiol. 1992, 9, 177-184. [CrossRef]

132. Rapado, A.; Hawkins, F.; Sobrinho, L.; Díaz-Curiel, M.; Galvao-Telles, A.; Arver, S.; Melo Gomes, J.; Mazer, N.; Garcia e Costa, J.; Horcajada, C.; et al. Bone Mineral Density and Androgen Levels in Elderly Males. Calcif. Tissue Int. 1999, 65, 417-421. [CrossRef]

133. Ritter, C.S.; Brown, A.J. Suppression of PTH by the vitamin D analog eldecalcitol is modulated by its high affinity for the serum vitamin D-binding protein and resistance to metabolism. J. Cell. Biochem. 2011, 112, 1348-1352. [CrossRef]

134. Martineau, A.R.; Wilkinson, R.J.; Wilkinson, K.A.; Newton, S.M.; Kampmann, B.; Hall, B.M.; Packe, G.E.; Davidson, R.N.; Eldridge, S.M.; Maunsell, Z.J.; et al. A Single Dose of Vitamin D Enhances Immunity to Mycobacteria. Am. J. Respir. Crit. Care Med. 2007, 176, 208-213. [CrossRef]

135. Daffara, V.; Verdoia, M.; Rolla, R.; Nardin, M.; Marino, P.; Bellomo, G.; Carriero, A.; Luca, G.D. Impact of polymorphism rs7041 and rs4588 of Vitamin D Binding Protein on the extent of coronary artery disease. Nutr. Metab. Cardiovasc. Dis. 2017, 27, 775-783. [CrossRef]

Publisher's Note: MDPI stays neutral with regard to jurisdictional claims in published maps and institutional affiliations.

(C) 2020 by the authors. Licensee MDPI, Basel, Switzerland. This article is an open access article distributed under the terms and conditions of the Creative Commons Attribution (CC BY) license (http://creativecommons.org/licenses/by/4.0/). 